\title{
Pelatihan Mendeley untuk Menunjang Karya Ilmiah Guru-Guru SMAN Titian Teras H. Abdurrahman Sayoeti
}

\author{
Ali Sadikin ${ }^{1}$, Asni Johari ${ }^{1}$, Jodion Siburian' ${ }^{1}$, Ervan Johan Wicaksana ${ }^{1}$, dan Desfaur Natalia ${ }^{1}$ \\ ${ }^{1}$ Universitas Jambi, Jl. Raya Jambi-Ma.Bulian KM.15 Mendalo Indah, Kec. Jaluko Kab.Muaro Jambi-Jambi 36361 \\ *Email koresponden: alisadikin@unja.ac.id
}

\author{
ARTICLE INFO \\ Article history \\ Received: 23 Ags 2020 \\ Accepted: 03 Apr 2021 \\ Published: 23 Apr 2021
}

\section{Kata kunci:}

Guru SMA

Karya Ilmiah

Mendeley

\begin{abstract}
A B S T R A K
Background: Menulis karya ilmiah merupakan tuntutan guru dalam meningkatkan profesionalisme. Mendeley adalah salah satu aplikasi penulisan daftar pustaka yang diperlukan untuk menunjang keterampilan menulis karya ilmiah. Pengabdian ini bertujuan untuk meningkatkan keterampilan Guru-Guru di SMA N Titian Teras H. Abdurrahman Sayoeti dalam menggunakan Mendeley Metode: Metode pelatihan dilakukan dengan ceramah, diskusi dan praktik. Kegiatan pertama yaitu memperkenalkan aplikasi mendeley, lalu menginstal aplikasi mendeley di laptop masing-masing peserta. Mengumpulkan referensi di aplikasi mendeley untuk dapat digunakan dalam penulisan karya ilmiah dan terakhir menerapkan aplikasi Mendeley dalam penulisan karya ilmiah. Hasil: guru-guru dapat menggunakan aplikasi mendeley dengan baik dan benar sehingga dapat menunjang kegiatan menulis karya ilmiah. Dengan keterampilan tersebut guru akan mudah mencari literasi dan memudahkan dalam menulis daftar pustaka secara otomatis. Kesimpulan: guru-guru di SMA N Titian Teras H. Abdurrahman Sayoeti dapat menggunakan aplikasi Mendeley dalam penulisan karya ilmiah.
\end{abstract}

\section{A B S T R A C T}

Keyword:

High school teacher

Mendeley

Scientific work
Background: Writing scientific papers is a teacher's requirement in increasing professionalism. Mendeley is one of the bibliography writing applications needed to support scientific writing skills. This service aims to improve the skills of teachers at SMA N Titian Teras H. Abdurrahman Sayoeti in using Mendeley. Methods: The training method is carried out by lectures, discussions and practices. The first activity is introducing the Mendeley application, then installing the Mendeley application on each participant's laptop. Collecting references in the Mendeley application to be used in writing scientific papers and finally applying the Mendeley application in writing scientific papers. Results: Teachers can use the Mendeley application properly and correctly so that it can support writing activities of scientific papers. With these skills the teacher will easily search for literacy and make it easier to write bibliography automatically. Conclusions: Teachers at SMA N Titian Teras H. Abdurrahman Sayoeti can use the Mendeley application in writing scientific papers.

(c) 2021 by authors. Lisensi Jurnal Solma, UHAMKA, Jakarta. Artikel ini bersifat open access yang didistribusikan di bawah syarat dan ketentuan Creative Commons Attribution (CC-BY) license.

\section{PENDAHULUAN}

SMA Negeri Titian Teras H. Abdurrahman Sayoeti Jambi adalah sebuah sekolah menengah atas berasrama yang didirikan pada 14 Juli 1994. SMA ini memiliki siswa kurang lebih 600 orang siswa. SMA Negeri H. Abdurahaman Sayoeti merupakan sekolah ternama dan unggul yang dimiliki Propinsi Jambi. Sekolah ini beralamat di Jl. Raya Jambi-Ma.Bulian KM. 21 Pijoan Kabupaten Muaro Jambi. Sama-sama di kecamatan Jambi Luar Kota (Jaluko) dengan Universitas 
Jambi (Marmoah, 2017). Jarak antara Kampus Pinang Masak Universitas Jambi dengan SMA N Titian Teras hanya berjarak 6 km. SMA Negeri yang dipimpin oleh Bapak Pahrin Wirnadian, S.Pd., M.Si ini terus mengalami perbaikan dan peningkatan kualitas baik SDM guru, pegawai maupun siswanya. Akan tetapi dalam penulisan karya ilmiah guru-guru SMA N Titian Teras masih mengalami kesulitan dalam menggunakan aplikasi daftar Pustaka. Maka untuk mendukung keterampilan guru tersebut perlu diadakan pelatihan penggunaan aplikasi dalam Menyusun daftar Pustaka (Rahmawati et al., 2018).

Salah satu aplikasi untuk Menyusun daftar Pustaka adalah Mendeley, software pengelola referensi atau daftar Pustaka yang dapat mengorganisir penelitian (Djamaris, 2017). Penggunaan mendeley dalam sebuah karya ilmiah merupakan suatu keharusan mengingat saat ini kita berada di era revolusi industri 4.0. Di era teknologi seperti saat ini alangkah malunya apabila kita masih memakai cara-cara manual dalam menulis (Sadikin \& Hakim, 2019). Aplikasi Mendeley sangat mudah digunakan dan sifatnya online (Windarto et al., 2018). Penggunaan Mendeley memudahkan dalam pengelolaan referensi dalam mendukung penulisan karya ilmiah (Ginanjar, 2019). Dengan aplikasi ini semua sumber dapat di hubungkan dan mudah untuk dicek dalam sebuah daftar pustaka secara online (Isa et al., 2016). Sehingga plagiasi tidak akan terjadi karena semua sumber dihubungkan langsung dengan mendeley.

Penggunaan mendeley dapat memudahkan penulis untuk mengorganisasi tulisan, dan valid sehingga tidak perlu lagi mengecek satu persatu apakah referensi yang kita kutip sudah tertulis di daftar pustaka atau belum. Cara-cara manual tidak lagi dipakai dalam penulisan karya ilmiah dewasa ini bahkan akan ditolak ketika kita menulis artikel di jurnal yang bereputasi (Sejati, 2017). Dengan pelatihan menggunakan sofware mendeley ini para guru akan dapat menulis karya ilmiah berkualitas (Pahmi et al., 2018). Aplikasi mendeley ini memudahkan juga memudahkan penulis dalam mengelola file-file artikel ilmiah yang telah ditulisnya sehingga menjadi rapi dan mudah untuk dikutip serta membuat abstrak (Windarto et al., 2018).

Diperlukan juga pedoman atau pun modul untuk dapat digunakan sebagai penuntun dalam menggunakan aplikasi mendeley ini. sehingga para guru dan penulis tidak kebingungan dalam menerapkan aplikasi ini (Ginanjar, 2019). Dengan menulis guru akan menjadi terbiasa untuk menghasilkan karya dari penelitian yang dilakukkannya. Baik itu penelitian tindakan kelas, lesson study maupun eksperimen (Fitriyadi, 2013). Dengan menulis karya ilmiah akan meningkatkan profesionalisme guru dalam dunia akademik (Aina et al., 2015). Menulis karya ilmiah masih menjadi kesulitan bagi guru dengan latar belakang waktu yang tidak ada, tidak ada tim, dan kurang motivasi (Sadikin et al., 2019). Untuk itulah dengan pelatihan mendeley ini diharapkan nantinya dapat memberikan keterampilan bagi guru dalam mencari dan mengutip referensi. Dengan harapan timbul motivasi untuk menulis bagi guru.

Ada pun cara untuk menjawab tantangan kemajuan era revolusi industri 4.0 ini adalah dengan mempelajari teknologi yang dibutuhkan untuk mempercepat kerja kita (Shahroom \& Hussin, 2018), Salah satunya adalah dengan menggunakan aplikasi mendeley (Rahmawati et al., 2018). Dengan aplikasi ini banyak keuntungan yang didapatkan, Guru menjadi mudah dalam menyusun daftar rujukan (Trisasti, 2014), mudah dalam mencari referensi, mudah dalam mengecek jurnal yang bereputasi (Mubarok, 2018). Tidak perlu lagi mengecek secara manual apakah sudah valid referensi yang digunakan (Ruslan et al., 2013).

\section{MASALAH}

Guru-guru di SMAN Titian Teras H. Aburahman Sayoeti Jambi belum memiliki pengetahuan dan keterampilan dalam menggunakan mendeley. Keadaan ini membuat guru-guru mengalami kendala dalam menulis karya ilmiah dan mencari literasi di internet. Sehingga guru- 
guru kurang berminat untuk menulis. Maka dari itu solusi yang ditawarkan TIM PPM Prodi pendidikan biologi Universitas Jambi adalah memberikan pelatihan mendeley untuk meningkatkan keterampilan pengelolaan daftar Pustaka guru di SMA N Titian Teras $\mathrm{H}$. Aburahman Sayoeti Jambi.

\section{METODE PELAKSANAAN}

Kegiatan PPM ini dilaksanakan pada hari rabu 22 juli 2020 mulai pukul 08.00-13.00 WIB bertempat di laboratorium Teknologi Informassi dan Komunikasi SMA N Titian Teras $\mathrm{H}$. Abdurrahman Sayoeti. Dengan agenda kegiatan:

Tabel 1. Agenda Kegiatan PKM

\begin{tabular}{|c|c|c|}
\hline Pukul & Materi & Narasumber \\
\hline 08.00-08.30 WIB & Manfaat Mendeley & Prof. Dr. Asni Johari, M.Si \\
\hline 08.30-09.00 WIB & Instan aplikasi Mendeley & Dr. Ervan Johan Wicaksana, S.Pd. M.Pd., M.Pd.I \\
\hline 09.00-10.00 WIB & $\begin{array}{l}\text { Mencari referensi dan } \\
\text { menginput ke Mendeley }\end{array}$ & Dr. Drs. Jodion Siburian, M.Si \\
\hline 10.00-11.00 WIB & $\begin{array}{l}\text { Menggunakan Mendeley } \\
\text { dalam karya ilmiah }\end{array}$ & Ali Sadikin, S.Pd.I,M.Pd \\
\hline 11.00-12.00 WIB & $\begin{array}{l}\text { Menginput referensi online } \\
\text { ke Mendeley }\end{array}$ & Desfaur Natalia \\
\hline 12.00-13.00 WIB & Praktik oleh peserta & TIM PPM \\
\hline
\end{tabular}

Pelatihan Mendeley Untuk Menunjang Karya Ilmiah Guru-Guru SMAN Titian Teras H. Abdurrahman Sayoeti akan dilaksanakan dengan metode sebagai berikut:

\section{Ceramah}

Metode ini digunakan sebagai pembuka wawasan guru tentang pengetahuan mereka terhadap aplikasi mendeley. Apakah sudah tahu atau belum. Kalau sudah tahu sejauh mana dan kalau belum akan dijelaskan oleh tim PPM.

Tabel 2. Jadwal Pemyampaian Materi Mendeley

\begin{tabular}{|c|c|c|c|}
\hline No. & Nama & Asal Instansi & Keahlian \\
\hline 1. & $\begin{array}{c}\text { Dr. Drs. Jodion Siburian, } \\
\text { M.Si }\end{array}$ & $\begin{array}{c}\text { Prodi Pendidikan Biologi FKIP } \\
\text { Universitas Jambi }\end{array}$ & $\begin{array}{l}\text { Pendidikan Biologi/Struktur } \\
\text { dan Perkembangan Hewan }\end{array}$ \\
\hline 2. & Ali Sadikin, M.Pd & $\begin{array}{c}\text { Prodi Pendidikan Biologi FKIP } \\
\text { Universitas Jambi }\end{array}$ & Pendidikan Biologi \\
\hline 3. & Prof. Dr. Asni Johari, M.Si & $\begin{array}{c}\text { Prodi Pendidikan Biologi FKIP } \\
\text { Universitas Jambi }\end{array}$ & Entomologi \\
\hline 4. & $\begin{array}{l}\text { Dr. Ervan Johan Wicaksana, } \\
\text { S.Pd., M.Pd, M.Pd.I }\end{array}$ & $\begin{array}{c}\text { Prodi Pendidikan Biologi FKIP } \\
\text { Universitas Jambi }\end{array}$ & Pendidikan Biologi \\
\hline 5. & Desfaur Natalia, S.Pd.M.Pd & $\begin{array}{c}\text { Prodi Pendidikan Biologi FKIP } \\
\text { Universitas Jambi }\end{array}$ & Pendidikan Biologi \\
\hline
\end{tabular}

2. Diskusi

Menggali minat dan motivasi guru dalam mempelajari aplikasi mendeley yang akan digunakan dalam menulis karya ilmiah dengan harapan guru menjadi termotivasi dan mau menulis karya ilmiah dengan bantuan aplikasi mendeley. 


\section{Praktikum}

Dengan metode pratikum guru akan dibimbing selangkah demi selangkah cara menggunakan mendeley. Semua guru harus membawa laptop atau komputer untuk menginstal aplikasi mendeley. Kemudian menggunakan aplikasi ini untuk mengorganisasikan referensi yang sudah dimiliki dan mencari referensi yang dibutuhkan untuk menulis sebuah karya ilmiah.

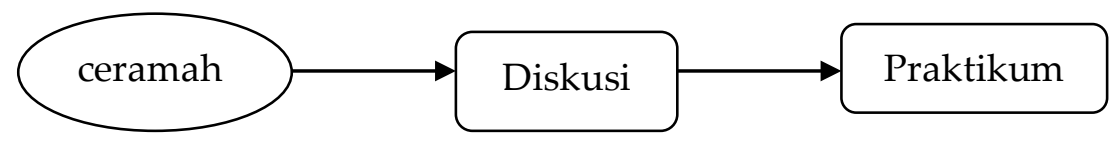

Gambar 1. Metode Pelaksanaan pengabdian

Tim PPM FKIP Universitas Jambi telah memiliki pengalaman dalam menulis karya ilmiah baik skala jurnal nasional terakreditasi di sinta 1-4. Bahkan sudah ada yang menulis di jurnal internasional terkreditasi di Q1, Q2, Q3 dan Q4. Tidaklah mudah untuk dapat masuk dan publis di jurnal internasional apalagi di Q1. Membutuhkan waktu, kesabaran, dan tim yang solid dalam membuat tulisan berkualitas baik itu referensinya maupun data dan metode yang digunakan.

\section{HASIL DAN PEMBAHASAN}

Kegiatan pengabdian di SMA N Titian Teras H. Abdurahman Sayoeti disambut antusias oleh kepala sekolah Bapak Pahrin, S.Pd, M.Si. Kepala sekolah terbaik se-Indonesia ini menyatakan bahwa pelatihan mendeley dibutuhkan untuk menunjang keterampilan guru dalam menulis karya ilmiah. Kegiatan PPM ini dilaksanakan pada hari rabu 22 juli 2020 mulai pukul 08.00-13.00 WIB. Kegiatan diawali dengan pembukaan acara yang dibuka langsung oleh kepala sekolah.

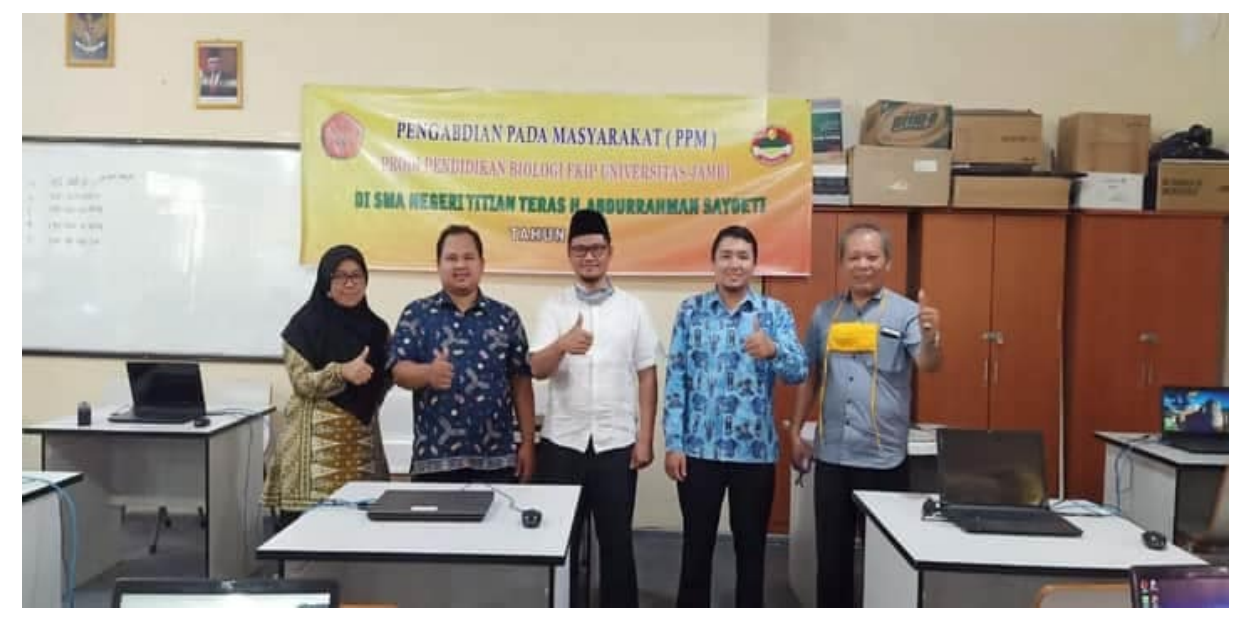

Gambar 2. Kepala sekolah menyambut Tim PPM Universitas Jambi

Dalam kegiatan ini mulanya guru-guru terlihat kurang antusias mengikuti pelatihan. Hal ini terbukti dari banyak yang bermain hand phone dan laptop dengan membuka whatsapp. Namun, ketika materi dimulai dengan pemaparan oleh bapak Ali Sadikin, S.Pd.I, M.Pd tentang penggunaan aplikasi mendeley dalam menulis daftar pustaka dan pengutipan mereka langsung tertarik. Indikator terlihat dari 27 orang guru yang mengikuti pelatihan Mendeley 24 orang guru $(88 \%)$ terlihat memperhatikan materi yang disampaikan narasumber. Hal ini dikarenakan mereka belum pernah menggunakan mendeley dalam mengutip maupun menulis daftar pustaka. Sampaisampai salah seorang peserta mengatakan: "ooo ini yang saya cari selama ini, ternyata mudah ya 
digunakan", Kata salah seorang guru. Aplikasi Mendeley memang memudahkan penulis dalama mengelola daftar Pustaka (Pahmi et al., 2018).

Kemudian para guru terlihat antusias dalam menginstal aplikasi mendeley. Lalu menggunakannya dalam pengutipan menggunakan google scholar. Pertama diajarkan tim PPM cara mendowload aplikasi mendeley (Paramudyta, 2015), kemudian menginstalnya. Kedua, memasukkan daftar buku dan jurnal untuk literasi baik secara manual maupun online. Ketiga, mengutip menggunakan mendeley dalam sebuah tulisan. Keempat, insert daftar pustaka otomatis dari hasil pengutipan (Listihana \& Nofrizal, 2018). Mendeley dapat mengelola daftar Pustaka langsung terhubung dengan google scholar (Ginanjar, 2019). Penggunaan aplikasi Mendeley dapat meningkatkan pengetahuan dan keterampilan peserta dalam menulis karya ilmiah (Fernandez et al., 2020).

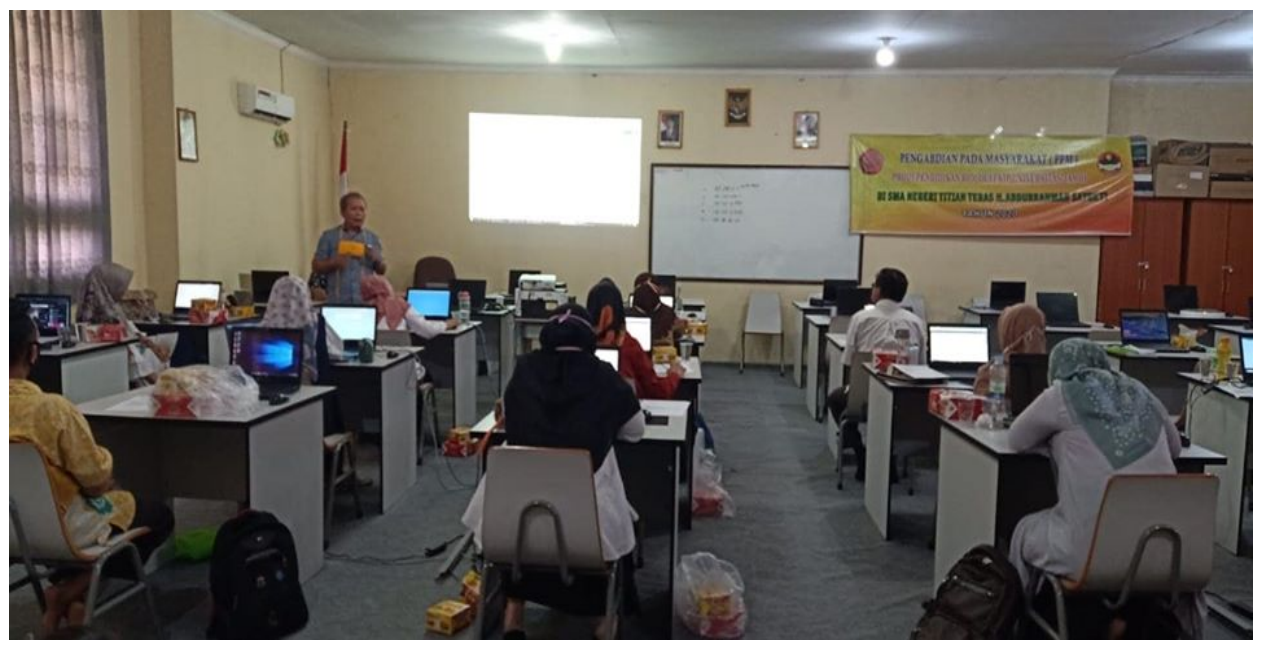

Gambar 3. Pelaksanaan PPM

Tahap selanjutnya adalah membuka tanya jawab dengan guru-guru, banyak yang bertanya tentang cara mengutip, cara memasukkan kutipan, cara menulis daftar pustaka dan mencari literasi secara online. Terakhir, tim PPM membagikan survei untuk mengevaluasi kegiatan yang dilakukan. Hasil survey menunjukkan bahwa keterampilan guru meningkat dalam menulis karya ilmiah. Para guru menghendaki untuk diadakan lagi kegiatan serupa dengan tema yang berbeda. Mereka mengucapkan terima kasih atas kegiatan PPM itu.

Luaran yang dicapai dalam PPM ini adalah peningkatan keterampilan guru dalam menggunakan mendeley dalam mengutip literasi baik manual maupun secara online. Hasilnya guru-guru dapat menggunakan aplikasi mendeley dengan baik dan benar sehingga dapat menunjang kegiatan menulis karya ilmiah. Dengan keterampilan tersebut guru akan mudah mencari literasi dan memudahkan dalam menulis daftar pustaka secara otomatis. Keterampilan guru harus terus ditingkatkan untuk menunjang kompetensi profesionalisme (Somantri et al., 2019). Rencana tahapan setelah kegiatan pengabdian pada masyarakat ini adalah kami akan melaksanakan kegaitan ini ditempat lain dengan perbaikan-perbaikan materi sesuai dengan aspirasi guru-guru biologi. Diantaranya adalah penulisan karya ilmiah, pencarian literasi dan pelatihan laboratorium. Karena berdasarkan observasi ternyata ketiga materi itu yang sangat diharapkan. 


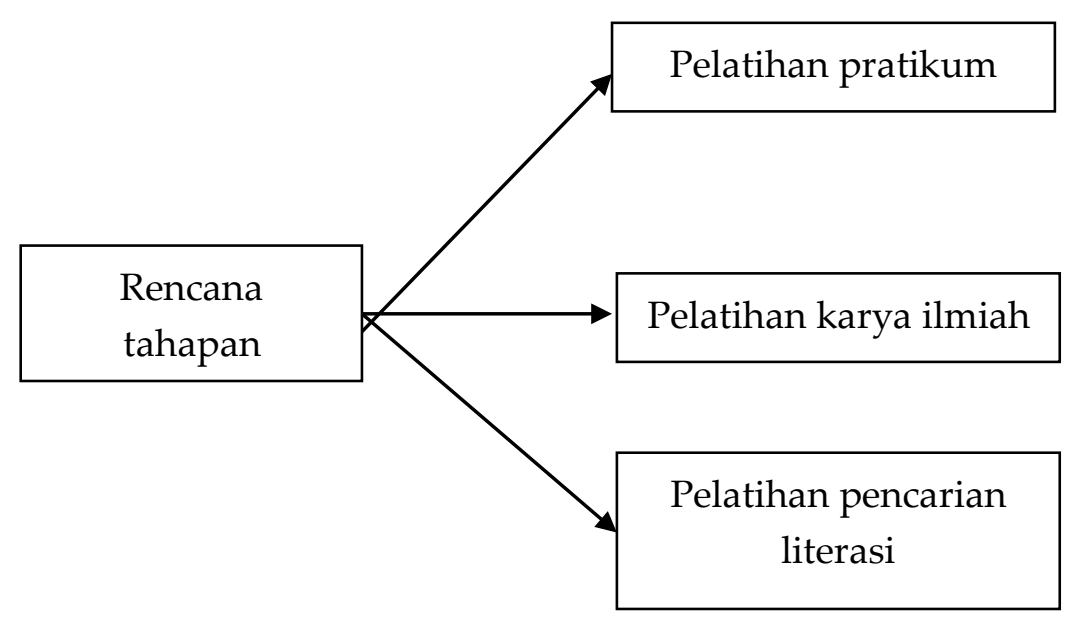

Gambar 4. Rencana Tahapan berikutnya

\section{KESIMPULAN}

Hasil kegiatan pengabdian kepada masyarakat ini telah berhasil membuat guru-guru SMAN Titian Teras H. Abdurahman Sayoeti terampil menggunakan mendeley. Apalikasi ini memudahkan guru dalam mengutip baik secara manual maupun online. Sehingga guru-guru dalam mudah mencari literasi dalam menulis karya ilmiah. Dengan keterampilan tersebut guruguru akan menjadi profesional dalam menjalankan tugasnya.

\section{UCAPAN TERIMA KASIH}

Kami mengucapkan terima kasih kepada Ketua LPPM Universitas Jambi dan Dekan FKIP Universitas Jambi yang telah mendanai kegiatan PPM ini. Untuk itu kami berharap kegiatan dukungan ini terus berlanjut dan kami juga mengucapkan terima kasih kepada kepala sekolah dan guru yang telah menerima kegiatan ini dengan penuh antusias.

\section{DAFTAR PUSTAKA}

Aina, M., Bambang, H., Retni, S. B., Afreni, H., \& Sadikin, A. (2015). Pelatihan penulisan karya tulis ilmiah bagi guru guru SMA 8 Kota Jambi. Jurnal Pengabdian Pada Masyarakat, 30(3).

Djamaris, A. (2017). Panduan Penggunaan Mendeley (Versi 1.17. 10).

Fernandez, D., Merina, M., \& Susilo, S. (2020). Pelatihan Teknik Sitasi dan Pencarian Referensi untuk Meningkatkan Publikasi Ilmiah di Universitas Muhammadiyah Sumatera Barat. Jurnal SOLMA, 9(1), 113-120.

Fitriyadi, H. (2013). Integrasi Teknologi Informasi Komunikasi Dalam Pendidikan: Potensi Manfaat, Masyarakat Berbasis Pengetahuan, Pendidikan Nilai, Strategi Implementasi Dan Pengembangan Profesional. Jurnal Pendidikan Teknologi Dan Kejuruan, 21(3), 269-283. https://doi.org/10.21831/jptk.v21i3.3255

Ginanjar, A. (2019). Peningkatan Mutu Karya Tulis Dosen FIS Dengan Menggunakan Reference Manager Software Mendeley. Harmony, 3(2), 199-203.

Isa, S. M., Soewito, B., \& Gunawan, F. E. (2016). Pengaruh Perangkat Lunak Managemen Referensi Pada Peningkatkan Motivasi Publikasi Para Pendidik. Ethos (Jurnal Penelitian Dan Pengabdian Masyarakat), 4(2), 243-248.

Listihana, D., \& Nofrizal, N. . (2018). Mendeley: untuk Meningkatkan Kemampuan Menulis Dosen. MARTABE: Jurnal Pengabdian Masyarakat, 1(1), 49-55. 
Marmoah, S. (2017). Manajemen Sarana dan Prasarana di Sekolah Menengah Atas (SMA) Negeri Titian Teras Muaro Jambi. Jurnal Ilmiah Universitas Batanghari Jambi, 14(4), 26-35. https://doi.org/http://dx.doi.org/10.33087/jiubj.v14i4.219

Mubarok, F. K. (2018). Manajemen Referensi Berbasis Aplikasi Mendeley untuk Jurnal Ilmiah. 2.

Pahmi, P., Ardiya, A., Syahfutra, W., Wibowo, A. P., Niah, S., \& Febtiningsih, P. (2018). Pelatihan penggunaan Mendeley untuk referensi dalam menulis karya ilmiah bagi guru SMA Handayani Pekanbaru. Jurnal Pengabdian UntukMu NegeRI, 2(2), 35-39.

Paramudyta, D. A. (2015). Pemanfaatan Mendeley Sebagai Program Citation Management di Perpustakaan Fakultas Kedokteran Unuversitas Gadjah Mada Yogyakarta. Universitas Islam Negeri Sunan Kalija.

Rahmawati, C., Meliyana, M., Yuliana, Y., \& Zain, H. (2018). Pelatihan Software Mendeley Dalam Peningkatan Kualitas Artikel Ilmiah Bagi Dosen. Jurnal Pengabdian Kepada Masyarakat, 8(1), 30. https://doi.org/10.30999/jpkm.v8i1.200

Ruslan, I., Wibowo, A., \& Lim, R. (2013). Website Penelusuran Artikel Ilmiah dengan Memanfaatkan Parscit, Google Scholar dan Mendeley Api. Jurnal Infra, 1.

Sadikin, A., \& Hakim, N. (2019). Pengembangan Media E-Learning Interaktif Dalam Menyongsong Revolusi Industri 4 . Jurnal Ilmiah Pendidikan Biologi, 5(2), 131-138. https://doi.org/10.22437/bio.v5i2.7590

Sadikin, A., Johari, A., Subagyo, A., Budiarti, R. S., \& Hakim, N. (2019). Pelatihan Pembuatan Artikel Menembus Jurnal Nasional dan Internasional di SMA N 11 Muaro Jambi. Jurnal Karya Abdi Masyarakat, $3(1), 67-73$.

Sejati, A. W. (2017). Tutorial Sederhana Mendeley. Universitas Diponegoro. https://doi.org/10.31227/osf.io/eqn9d

Shahroom, A. A., \& Hussin, N. (2018). Industrial Revolution 4.0 and Education. International Journal of Academic Research in Business and Social Sciences, 8(9), 314-319. https://doi.org/10.6007/ijarbss/v8-i9/4593

Somantri, O., Abidin, T., Wijayanto, S., Wibowo, D. S., \& Dairoh, D. (2019). Peningkatan Kompetensi Guru melalui Pelatihan Keterampilan Pembuatan E-Presentation. Jurnal Solma, 8(2), 219-228.

Trisasti, L. (2014). Panduan Penggunaan Software Manajemen Referensi Mendeley. Teknologi, 1, 1-16.

Windarto, A. P., Hartama, D., Wanto, A., \& Parlina, I. (2018). Pelatihan Pemanfaatan Mendeley Desktop Sebagai Program Istimewa Untuk Akademisi Dalam Membuat Citasi Karya Ilmiah. AKSIOLOGIYA: Jurnal Pengabdian Kepada Masyarakat, 2(2), 145-150. https://doi.org/http://dx.doi.org/10.30651/aks.v2i2.1319 